\title{
Nonhematic Cells Count
}

National Cancer Institute

\section{Source}

National Cancer Institute. Nonhematic Cells Count. NCI Thesaurus. Code C147401.

The determination of the amount of nonhematic cells present in a sample. 